\title{
Rancang Bangun Modul Praktikum Teknik Digital Berbasis Mobile Augmented Reality (AR)
}

\author{
Elisa Usada \\ Sekolah Tinggi Teknologi Telematika Telkom Purwokerto \\ Jln. DI Panjaitan 128, Purwokerto 53147 \\ elisa@st3telkom.ac.id
}

\begin{abstract}
Abstrak - Praktikum merupakan salah satu jenis pembelajaran yang dilaksanakan untuk mengasah keterampilan dan memperdalam pemahaman mahasiswa akan suatu materi, dengan menggunakan peralatan-peralatan praktek. Pelaksanaan praktikum mengacu pada petunjuk praktikum dan modul berisi materi yang akan dipraktekkan. Perkembangan teknologi media belajar memungkinkan modul praktikum untuk dikemas dalam bentuk yang lebih menarik, selain dalam bentuk buku teks konvensional. Media belajar berbasis AR (Augmented Reality) telah digunakan untuk mendukung aplikasi edukasi dalam berbagai domain, seperti sejarah, matematika, dan sebagainya. Penelitian ini bertujuan merancang dan membangun modul praktikum mata kuliah Teknik Digital berbasis mobile AR. Metodologi yang akan digunakan adalah melalui pendekatan prototype dengan langkahlangkah: mengumpulkan dan menganalisa kebutuhan; perancangan; membangun protototype. Hasil dari penelitian ini adalah sebuah prototype modul mata praktikum Teknik Digital berbasis mobile-AR. Prototype yang dihasilkan belum menampilkan model 3D yang lengkap. Sebagai langkah penelitian lanjutan, pembuatan model 3D yang lengkap akan dibuat dan prototype ini harus melalui proses evaluasi oleh konsumen, dilanjutkan dengan perubahan rancangan dan prototype apabila diperlukan, sebelum dibuat dalam skala besar dan diimplementasikan.
\end{abstract}

Kata kunci - Modul Praktikum Berbasis AR, Mobile AR

Abstract - Practicum is one of learning method which is run in laboratorium and has purposes to improve the student's skills and help the student mastering the subject material by using some laboratorium instruments. The practicum is being run using the practicum modul as a guidelines. The evolution in learning media technology enable to construct more interesting practicum modul instead of the old conventional text book. AR based learning media has been used to support learning media in a number of fields, including history, mathematics, and many more. The purposes of this research are to design and develop the mobile AR based practicum modul of Digital Techniques (Teknik Digital). Prototype approach will be used in the research method, including steps; colecting and analyzing the requirements; designing; developing the prototype. The research result is a mobile AR based practicum modul of Digital Techniques prototype. The prototype is not showing the fix and completed 3D model yet. Constructing the completed 3D model, user evaluation, modification and improvement of the prototype design if needed are kept to the next research.

Keywords-AR Based Practicum Learning Media, Mobile AR

\section{Pendahuluan}

Metode praktikum adalah cara penyajian pelajaran dengan menggunakan percobaan [4]. Metode praktikum melibatkan pengamatan dan penggunaan alat-alat praktikum. Peserta praktikum atau praktikan pada umumnya dibekali dengan modul praktikum yang berisi materi praktikum disertai panduan pelaksanaan praktikum. Modul praktikum dapat berupa buku teks atau bentuk softcopy.

Teknologi AR (Augmented Reality) adalah teknologi yang menggabungkan tampilan konten yang dibangkitkan oleh komputer dengan tampilan video (live video) dunia nyata secara real time [2]. Paul Milgram dan Fumio Kishino menggambarkan perbedaan antara AR dengan VR (Virtual Reality) dalam Milgram's Reality-Virtuality Continuum. Tujuan teknologi AR adalah menyederhanakan berbagai hal untuk pengguna dengan membawa informasi virtual ke dalam lingkungan pengguna.

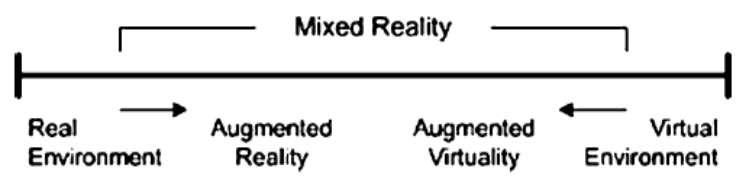

Gambar 1. Milgram's reality-virtuality continuum

AR telah diterapkan secara luas dalam bidang industri, seni, hiburan, game, iklan, kesehatan dan sebagainya. Teknologi AR juga telah diterapkan dalam bidang edukasi, yaitu sebagai opsi media belajar. Faktanya AR digunakan untuk mendukung berbagai aplikasi edukasi di bermacam-macam domain seperti sejarah, matematika, dan sebagainya [1]. Salah satu keunggulan AR adalah AR memiliki potensi untuk 
membawa situasi tempat belajar (laboratorium) ke dalam lingkup kehidupan sehari-hari mahasiswa [3].

Prinsip cara kerja AR adalah tracking (pelacakan) dan reconstruction (rekonstruksi). Pertama marker dideteksi melalui gambar dari webcam. Mekanisme deteksi (tracking) dapat melibatkan bermacam-macam algoritma misal edge detection, atau algoritma image processing lainnya. Data yang didapatkan dari langkah tracking digunakan dalam rekonstruksi sistem koordinat di dunia nyata. Contoh penerapan AR digambarkan dalam Gambar 2, marker berupa kotak hitam dengan teks AR di bagian tengah, ketika diarahkan ke webcam maka memunculkan objek 3D struktur kepala manusia.

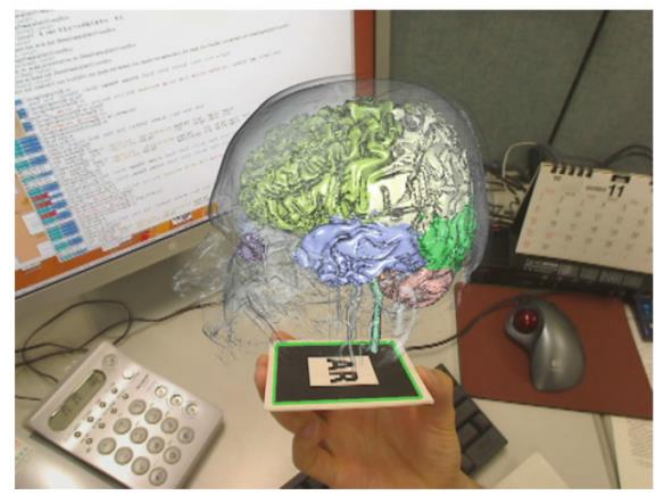

Gambar 2. Contoh penerapan AR dalam edukasi [2]

Penerapan aplikasi AR dapat berbasis desktop maupun mobile. Aplikasi AR berbasis mobile memiliki keunggulan dalam hal keleluasaan karena cukup berbekal handphone Android yang terkoneksi internet, sehingga mudah dibawa dan dilihat ketika berada di berbagai tempat. Berdasarkan paparan di atas maka penulis tertarik untuk membuat rancang bangun modul praktikum berbasis mobile $A R$ dalam penelitian ini.

Tujuan dari penelitian ini adalah untuk membuat prototype modul praktikum berbasis mobile $A R$. Cakupan materi modul yang dibuat adalah pada mata praktikum Teknik Digital di S1 Teknik Informatika ST3 Telkom Purwokerto. Batasan dari perangkat lunak yang dihasilkan adalah perangkat lunak masih berupa prototype yang belum dievaluasi oleh pengguna. Prototype yang akan dibuat belum menampilkan model 3D yang lengkap. Model 3D yang digunakan masih berupa model 3D sederhana.

\section{MEtOdOLOGI}

Metodologi yang digunakan adalah melalui pendekatan prototype. Pendekatan prototype sebenarnya adalah pengembangan dari model pengembangan perangkat lunak yang telah ada sebelumnya, yaitu model waterfall (air terjun). Langkah-langkah pengembangan dalam metode prototype hampir sama dengan model waterfall, hanya saja model prototype bersifat iteratif. Penanda proses iteratif adalah dengan adanya prototype (purwa rupa) atau bentuk sementara dari perangkat lunak. Prototype ini akan dievaluasi oleh konsumen terlebih dahulu sebelum dimulainya pengembangan perangkat lunak berskala besar, atau sebelum perangkat lunak tersebut diimplementasikan dalam dunia nyata.

Pengembangan prototype melibatkan langkahlangkah sebagai berikut [5]:

1. Mengumpulkan dan menganalisis kebutuhan

2. Melakukan perancangan cepat

3. Membangun sebuah prototype

4. Evaluasi prototype oleh pengguna

5. Perubahan rancangan dan prototype

6. Apabila pengguna kecewa dengan prototype yang telah dibangun maka ulangi langkah 5.

7. Apabila pengguna puas maka pembangunan skala besar atau implementasi dapat dilaksanakan.

Perubahan yang cepat dalam kegiatan perancangan dan pembangunan prototype merupakan faktor kritis dalam pendekatan prototype [5]. Oleh karena itu diperlukan tools yang bersifat reusable software, misalnya libraries atau SDK (Software Development Kit) yang sudah ada. Penelitian ini menggunakan SDK untuk aplikasi AR bernama Metaio.

Metaio merupakan SDK untuk pengembangan aplikasi mobile AR dengan dukungan multiplatform. Metaio dikembangkan oleh perusahaan Jerman, Metaio GmbH. Platform yang didukung oleh Metaio antara lain Android, IOS, Unity dan Windows. Metaio bersifat modular dengan komponen berikut ini:

1. Komponen untuk melakukan capture

2. Komponen untuk sensor antarmuka

3. Komponen rendering

4. Komponen tracking

5. Antarmuka Metaio SDK

SDK Metaio memerlukan lingkungan pengembangan Android untuk dapat bekerja. Oleh karena itu juga diperlukan ADT (Android Development Tools) dalam penelitian ini. ADT terdiri dari SDK Android dan IDE (Integrated Development Environment). SDK Android menyediakan API (Application Programming Interface) libraries dan perangkat pengembangan untuk membangun, testing, dan debug aplikasi-apalikasi Android.

Modul AR yang akan dibuat dalam penelitian ini berbasis platform Android dan akan dibuat menggunakan komputer dengan sistem operasi Windows 7. 


\section{HASIL DAN PEMBAHASAN}

\section{A. Rancangan Alur Penggunaan Perangkat Lunak}

Bentuk perangkat lunak yang akan dibuat adalah berupa buku teks modul praktikum yang dilengkapi visualisasi AR. Teknologi AR akan digunakan dalam memvisualisasikan perangkat praktikum yang digambarkan di dalam buku teks modul. Alur penggunaan perangkat lunak yang direncanakan digambarkan pada Gambar 3.

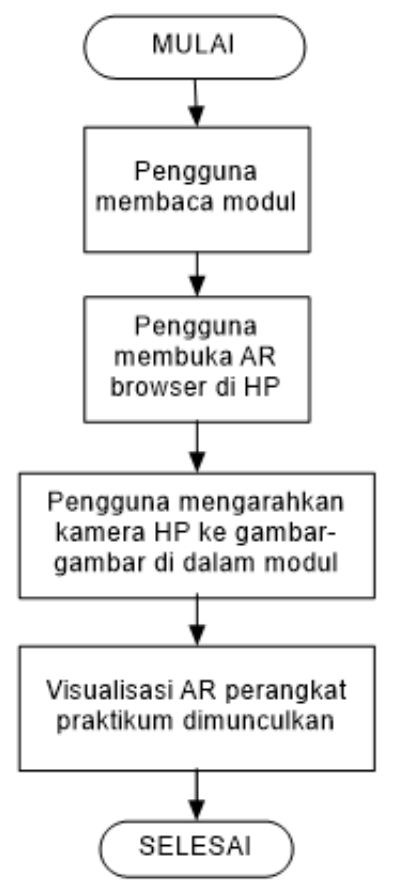

Gambar 3. Alur penggunaan perangkat lunak

\section{B. Materi Modul Praktikum}

Materi praktikum yang akan digunakan dalam penelitian ini dalah materi praktikum Teknik Digital. Kurikulum yang dijadikan acuan adalah GBPP Praktikum Teknik Digital untuk S1 Teknik Informatika ST3 Telkom Purwokerto. Ringkasan GBPP Praktikum Teknik Digital tersebut dapat dilihat pada Tabel 1.

Tabel 1. Ringkasan GBPP praktikum teknik digital

\begin{tabular}{ll}
\hline Pokok Bahasan & \multicolumn{1}{c}{ Sub Pokok Bahasan } \\
\hline $\begin{array}{l}\text { Rangkaian } \\
\text { Logika Dasar }\end{array}$ & b) $\begin{array}{l}\text { Mendesain rangkaian digital } \\
\text { dengan bantuan K-Map } \\
\text { Membuat rangkaian gerbang } \\
\text { logika pada papan trainer }\end{array}$ \\
& \\
Counter & $\begin{array}{l}\text { Membuat rangkaian pencacah } \\
\text { dengan papan trainer } \\
\text { a) }\end{array}$ \\
& $\begin{array}{l}\text { Membuat rangkaian register } \\
\text { serial dengan papan trainer } \\
\text { Register }\end{array}$ \\
& b) $\begin{array}{l}\text { Membuat rangkaian register } \\
\text { paralel dengan papan trainer }\end{array}$ \\
\hline
\end{tabular}

Perangkat praktikum Teknik Digital yang digunakan dalam modul adalah Leybold Kit, berupa papan trainer Leybold beserta gerbang-gerbang logika.

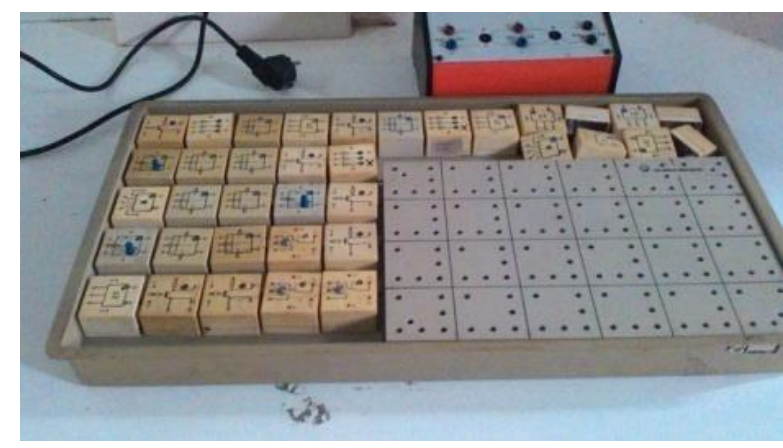

Gambar 4. Leybold trainer kit

Perangkat tersebut digunakan untuk membuat rangkaian logika. Pembuatan rangkaian logika harus dilandasi oleh kemampuan mengenai:

1. Sistem Bilangan Biner dan pengkodeannya

2. Aljabar Boole

3. Gerbang Logika beserta tabel kebenaran

4. Penyederhanaan persamaan logika

5. Penggambaran rangkaian logika

Materi modul praktikum yang digunakan di S1 Teknik Informatika ST3 Telkom dapat dilihat pada Tabel 2.

Tabel 2. Materi modul praktikum teknik digital

\begin{tabular}{|c|c|}
\hline Modul & Materi \\
\hline 1 & $\begin{array}{l}\text { a) Menyederhanakan persamanaan logika } \\
\text { b) Menggambarkan rangkaian logika } \\
\text { c) Membuat rangkaian logika berdasarkan } \\
\text { gambar yang dibuat menggunakan } \\
\text { papan Leybold } \\
\text { d) Mencocokkan hasil tabel kebenaran } \\
\text { dengan output yang dihasilkan di papan } \\
\text { Leybold. }\end{array}$ \\
\hline 2 & $\begin{array}{l}\text { a) Merancang rangkaian logika counter } \\
\text { b) Membuat rangkaian logika counter } \\
\text { menggunakan papan Leybold } \\
\text { berdasarkan gambar rancangan yang } \\
\text { telah dihasilkan } \\
\text { c) Mencocokkan hasil tabel kebenaran } \\
\text { dengan output yang dihasilkan } \\
\text { rangkaian logika counter pada papan } \\
\text { Leybold }\end{array}$ \\
\hline 3 & $\begin{array}{l}\text { a) Merancang rangkaian register pararel } \\
\text { maupun seri } \\
\text { b) Membuat rangkaian logika counter } \\
\text { menggunakan papan Leybold } \\
\text { berdasarkan gambar rancangan yang } \\
\text { telah dihasilkan } \\
\text { c) Mencocokkan output tabel kebenaran } \\
\text { dengan output yang dihasilkan } \\
\text { rangkaian register pada papan Leybold }\end{array}$ \\
\hline
\end{tabular}

\section{Analisa Kebutuhan}

Analisis kebutuhan merupakan proses mendapatkan informasi, model, spesifikasi tentang 
perangkat lunak yang diinginkan pengguna. Hasil analisa kebutuhan digambarkan pada Tabel 3.

Tabel 3. Analisis kebutuhan

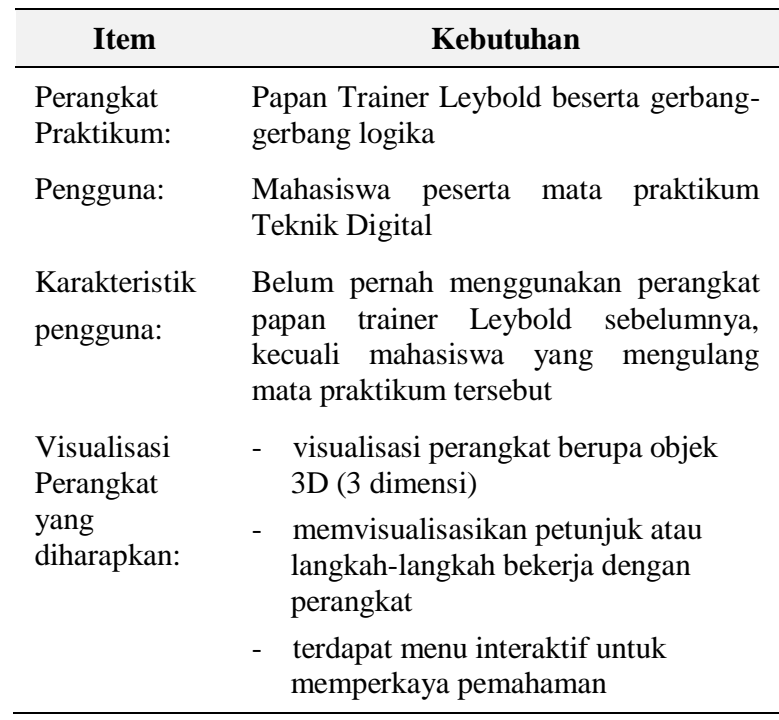

\section{Perancangan}

Modul yang akan dihasilkan direncanakan berbentuk buku teks dengan pengayaan visualisasi perangkat praktikum menggunakan teknologi AR. Contoh gambaran modul yang akan dibuat ditampilkan pada Gambar 4.

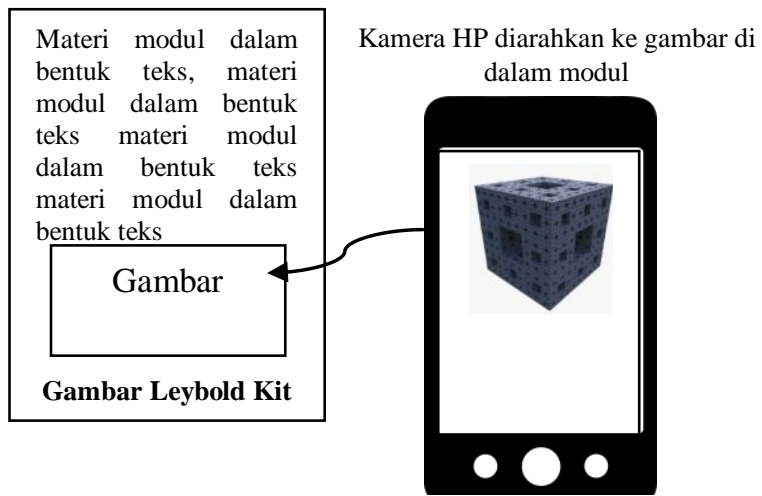

HP menampilkan visualisasi 3D dari perangkat praktikum

Gambar 4. Ilustrasi tampilan AR

Interaksi antara pengguna dengan perangkat lunak yang akan dibuat digambarkan dengan use case pada Gambar 5.

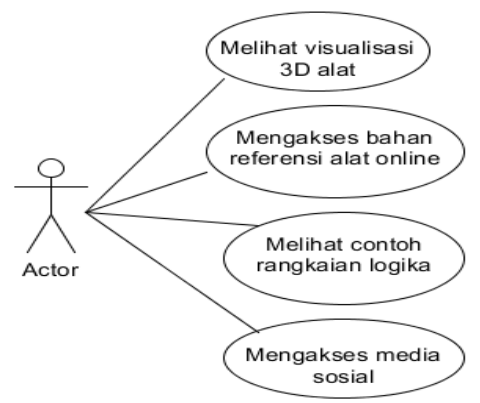

Gambar 5. Use case pengguna modul berbasis AR

\section{E. Pembuatan Prototype}

Pembuatan prototype memerlukan perangkat berikut ini:

1. Komputer dengan sistem operasi Windows 7 sebagai media pembuatan prototype

2. Handphone dengan sistem operasi Android sebagai tempat beroperasinya modul berbasis mobile AR yang akan dibuat. Spesifikasi handphone yang digunakan disesuaikan dengan dukungan yang dibutuhkan Metaio SDK, yaitu handphone dengan prosesor versi ARMv $7 \mathrm{ke}$ atas, mendukung OpenGLES 2.0, kamera, akselerometer, sensor magnetic dan GPS.

Perangkat lunak yang digunakan adalah:

1. Metaio SDK, Software Development Kit untuk pembuatan aplikasi AR.

2. ADT (Android Development Tools), perangkat lunak untuk membangun aplikasi berbasis Android, di dalamnya termasuk Android SDK dan Eclipse sebagai IDE (Integrated Development Environment).

Proses pembuatan prototype melibatkan observasi mengenai dukungan apa saja yang dibutuhkan agar Metaio SDK dapat bekerja. Dari hasil observasi maka dapat diketahui bahwa diperlukan Library tambahan yaitu:

1. Android adalah sistem yang dibangun menggunakan Java, sehingga perlu diperhatikan apakah JRE (Java Runtime Environment) yang digunakan oleh komputer mendukung versi ADT dan versi Android yang akan digunakan. ADT yang akan digunakan adalah ADT versi 22.0.1 dan Android yang digunakan adalah versi 4.2.2. kedua perangkat tersebut memerlukan JRE 1.6.

2. Proses pembuatan prototype akan melibatkan USB debugging dengan perangkat Android secara langsung, sehingga pada komputer perlu dilakukan instalasi driver handphone yang digunakan.

3. Google API's 17, merupakan library yang diperlukan untuk menjalankan aplikasi Android versi 4.2 ke atas.

Proses pra pembuatan prototype melibatkan langkah-langkah berikut:

1. Mengunduh Metaio dari website resmi Metaio kemudian melakukan instalasi di komputer.

2. Mengunduh ADT bundle, melakukan unzip.

3. Menjalankan IDE Eclipse.

4. Melakukan pengaturan JRE pada compiler Eclipse.

5. Melakukan import project Metaio untuk dijalankan di Eclipse.

6. Menghubungkan handphone menggunakan USB dan mengatur driver. 
7. Mengaktifkan pilihan USB debugging pada handphone.

8. Mulai membuat prototype di lingkungan Eclipse. Pembuatan prototype melibatkan proses pembuatan model 3D. Dalam penelitian ini model 3D yang dibuat masih berupa model 3D sederhana, belum berupa model 3D papan trainer Leybold.

9. Testing aplikasi dilakukan melalui USB debugging secara langsung.

Proses pembuatan Augmented Reality:

1. Mempersiapkan file yang akan digunakan sebagai marker, marker yang digunakan di dalam penelitian ini adalah gambar alat di dalam modul praktikum Teknik Digital. Marker yang menjadi referensi dalam penelitian ini memiliki ekstensi .png.

2. Mempersiapkan model 3D yang akan digunakan. Model 3D dapat dibangun menggunakan berbagai macam aplikasi 3D modeler seperti 3D's Max atau Blender. Metaio mendukung format model 3D dalam bentuk .obj untuk objek 3D statik dan bentuk .md2 atau .fbx untuk objek 3D dengan animasi.

3. Melakukan konfigurasi marker, method yang digunakan adalah method:

bool

setTrackingConfiguration(trackingDataFile);

method setTrackingConfigiration kemudian dipanggil dengan baris perintah berikut:

metaioSDK.setTrackingConfiguration(trackingD ataFile);

trackingDataFile diisi dengan path dimana file marker berada.

4. Proses loading model 3D dilakukan dengan menggunakan system call:

\section{IGeometry createGeometry(metaio3Dmodel);}

metaio3Dmodel diisi dengan path dimana file 3D berada. IGeometry merupakan class di dalam SDK yang berfungsi untuk mengontrol objek pada tampilan AR.

5. Untuk mengubah ukuran model dapat dilakukan dengan menggunakan method berikut:

setScale(Vector3d $(0.8,0.8,0.8))$;

method tersebut dapat dipanggil dengan baris perintah:

mModel.setScale(new Vector3d(0.8, 0.8, 0.8)); selain itu juga dapat digunakan method setTranslation() dan setRotation().

Hasil dari prototype modul berbasis mobile AR dapat dilihat pada Gambar 6.

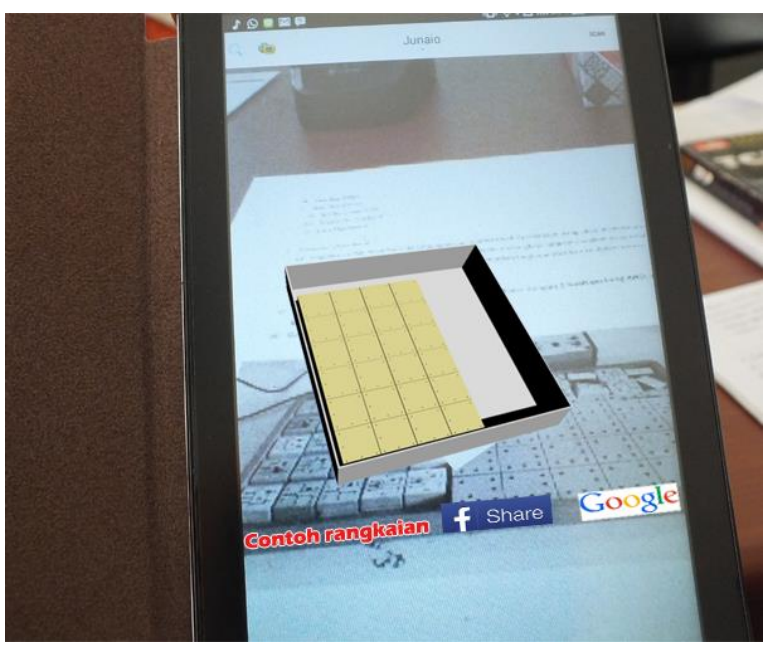

Gambar 6. Tampilan prototype

\section{KESIMPULAN DAN SARAN}

A. Kesimpulan

1. Langkah-langkah pembuatan modul praktikum berbasis AR:

a) Persiapan lingkungan pembangunan aplikasi berupa pengaturan hardware dan software

b) Pembuatan model 3D yang akan ditampilkan

c) Pembuatan dan konfigurasi marker

d) Pengaturan model 3D yang akan ditampilkan secara AR di lingkungan library AR

e) Testing

2. Dukungan perangkat keras dan perangkat lunak dalam pembuatan perangkat lunak berbasis mobile AR perlu diperhatikan dengan teliti karena pesan error yang muncul sering kali disebabkan oleh permasalahan support system.

B. Saran

1. Langkah pertama yang harus dilakukan untuk melanjutkan penelitian ini adalah pembuatan model 3D yang lengkap. Model 3D yang lengkap menyertakan juga cara kerja alat dalam visualisasi animasi.

2. Proses evaluasi yang akan dilakukan harus melibatkan mahasiswa peserta praktikum Teknik Digital.

3. Untuk meningkatkan sisi interaktifitas, pada penelitian selanjutnya dapat ditambahkan objek 3D yang dapat dimanipulasi oleh pengguna menggunakan sentuhan tangan pengguna. Metaio SDK telah mendukung fitur tersebut.

\section{DAFTAR PUSTAKA}

[1] Fuhrt, Borko, 2011, Handbook of Augmented Reality, Springer.

[2] Mullen, Tony, 2011, Prototyping Augmented Reality, John Wiley\&Sons, Inc, Indianapolis. 
[3] NN, 2005, 7 Things You Should Know About Augmented Reality, Educase Learning Initiative.

[4] SF. Kholid, S. Wawan, F. Eka, Metode Pembelajaran Praktikum untuk Meningkatkan Pemahaman Siswa pada Mata Pelajaran Multimedia di Sekolah
Menengah Kejuruan (Studi Kasus Siswa Kelas X di SMK Negeri 11 Cimahi). Universitas Pendidikan Indonesia.

[5] Simamarta, Janner, 2010, Rekayasa Perangkat Lunak, Penerbit ANDI. 